\title{
INDEX OF AUTHORS
}

ACKLEY, S F

ACKLEY, S F

ACKLEY, S F

AGNEW,TA

AKSENOV, Ye

ALLISON, I

ALLISON, I

ALLISON, I

ALLISON, I

ALLISON, I

ALLISON, I

ALLISON, I

ALT, B T

ANDERSON, M R

ANDERSON, M R

ANDERSON, M R

ARBLASTER, J M

ARCHER, A

BARBER, D G

BAREISS, J

BEGKMANN, A

BERTOIA, G

BERTOIA, G

BIN, C

BINDOFF, N L

BUDD, W F

BUSH, G M
A conceptual model for pancake-ice formation in a wave field

361

The Ronne polynya of 1997/98: observations of air-ice--ocean interaction

425

Snow-ice growth: a fresh-water flux inhibiting deep convection in the Weddell Sea, Antarctica

Investigating the anomalous sea-ice conditions in the Canadian High Arctic (Queen Elizabeth Islands) during summer 1998

The Arctic Ocean Circulation as simulated in a very high-resolution global ocean model (OCGAM)

A comparison of East Antarctic sea-ice motion derived using drifting buoys and remote sensing

Effects of regional fast-ice and iceberg distributions on the behaviour of the Mertz Glacier polynya, East Antarctica

Ice formation in the Mertz Glacier polynya, East Antarctica, during winter

Sea-ice growth and water-mass modification in the Mertz Glacier polynya, East Antarctica, during winter

Seasonal development of sea-ice thickness distribution in East Antarctica: measurements from upward-looking sonar data

Sensible- and latent-heat-flux estimates over the Mertz Glacier polynya, East Antarctica, from in-flight measurements

Sensitivity of the Antarctic sea-ice distribution to oceanic heat flux in a coupled atmospheresea-ice model

Investigating the anomalous sea-ice conditions in the Canadian High Arctic (Queen Elizabeth Islands) during summer 1998

Comparison of interannual snowmelt-onset dates with atmospheric conditions

567

391

The onset of Arctic sea-ice snowmelt as detected with passive- and active-microwave remote sensing

Spatial and temporal variability in snowmelt onset over Arctic sea ice

Sea ice and climate in 20th- and 21st-century simulations with a global atmosphere-oceanice model

Satellite observations of upper-ocean currents in Terra Nova Bay, Antarctica

A case-study in tracking 1998 polynya ice dynamics in Smith Sound, North Water polynya region, Canadian Arctic, using RADARSAT-1 data

An observational and modelling analysis of Laptev Sea (Arctic Ocean) ice variations during summer

The role of sea ice in the fresh-water budget of the Weddell Sea, Antarctica

Evaluation of operational SSM/I ice-concentration algorithms

Satellite observations of upper-ocean currents in Terra Nova Bay, Antarctica

Turbulent surface fluxes and air-ice coupling in Baltic-Air-Sea-Ice Study (BASIS)

Sea-ice growth and water-mass modification in the Mertz Glacier polynya, East Antarctica, during winter

Sensitivity of the Antarctic sea-ice distribution to oceanic heat flux in a coupled atmospheresea-ice model

Seasonal development of sea-ice thickness distribution in East Antarctica: measurements from upward-looking sonar data 
CHAPMAN, W L

CHENG, B

CHUNG, H

CHUNG, H

CHURUN, V

COALE, S L

COMISO, JC

COMISO, J C

CONNOLLEY,W

COON, M D

COWARD, A C

CRESSWELL, D

DAVIS, N R

DE ABREU, R

DEMING, J

DETHLOFF, K

DIECKMANN, G S

DIEGKMANN, GS

DIEGKMANN, G S

DIXON, T W

DMITRENKO, I

DOWNER, J

DRINKWATER, M R

DROBOT, S D

DROBOT, S D

DROBOT, S D

EHN, J

EICKEN, H

EICKEN, H

ELDER, B C

EMERY, W J

ENGBRODT, R

ENOMOTO, H

FORSTER, R R 20th-century sea-ice variations from observational data

Modelling sea-ice thermodynamics in BALTEX-BASIS

Calculation of wave propagation into land-fast ice

Dynamic, in situ measurement of sea-ice characteristic length

The Laptev Sea flaw polynya, Russian Arctic: effects on the mesoscale hydrography

Biomass, production and microhabitat characteristics near the freeboard of ice floes in the Ross Sea, Antarctica, during the austral summer

The Ronne polynya of 1997/98: observations of air-ice-ocean interaction

Satellite-observed variability and trend in sea-ice extent, surface temperature, albedo and clouds in the Arctic

The simulation of Antarctic sea ice in the Hadley Centre Climate Model (HadGM3)

Interannual variability of the sea-ice-induced salt flux in the Greenland Sea

385

The Arctic Ocean Circulation as simulated in a very high-resolution global ocean model (OCGAM)

Arctic sea-ice morphological characteristics in summer 1996

Islands) during summer 1998

A microscopic approach to investigate bacteria under in situ conditions in sea-ice samples

An observational and modelling analysis of Laptev Sea (Arctic Ocean) ice variations during summer

Behaviour of dissolved organic matter and inorganic nutrients during experimental sea-ice formation

Dissolved organic matter in Antarctic sea ice

Vertical zonation and community transition of sea-ice diatoms in fast ice and platelet layer, Weddell Sea, Antarctica

How a region of cracked sea ice affects ice-coupled wave propagation

The Laptev Sea flaw polynya, Russian Arctic: effects on the mesoscale hydrography

Ice-floe kinematics in the Ross Sea marginal ice zone using GPS and accelerometers

Combined satellite- and ULS-derived sea-ice flux in the Weddell Sea, Antarctica

Comparison of interannual snowmelt-onset dates with atmospheric conditions sensing

Spatial and temporal variability in snowmelt onset over Arctic sea ice

Time-series observations of the structure and properties of brackish ice in the Gulf of Finland

Indirect measurements of the mass balance of summer Arctic sea ice with an electromagnetic induction technique

A microscopic approach to investigate bacteria under in situ conditions in sea-ice samples

Temporal evolution of Arctic sea-ice temperature

A comparison of East Antarctic sea-ice motion derived using drifting buoys and remote sensing

Dissolved organic matter in Antarctic sea ice

Observation of sea-ice thickness fluctuation in the seasonal ice-covered area during 1992-99 winters

The onset of Arctic sea-ice snowmelt as detected with passive- and active-microwave remote sensing 
FOWLER, GW

FOX, C

FOX, C

FOX, C

FOX, C

FREW, R

FRITSEN, CH

GARRISON, DL

GASCARD, J-C

GASCARD, J-C

GEIGER, C A

GIANNELLI, V

GIANNELLI, V

GIBSON, A H

GILDOR, H

GOLDEN, K M

GOOSSE, H

GÖRGEN, K

GRANSKOG, M A

GRANSKOG, M A

GRIGIONI, P

GÜNTHER, S

HAAPALA, J

HAAPALA, J

HAARPAINTNER, J

HAARPAINTNER, J

HAARSMA, RJ

HAAS, G

HAAS, G

HAAS, G

HANSEN, J
A comparison of East Antarctic sea-ice motion derived using drifting buoys and remote sensing

Calculation of wave propagation into land-fast ice

Dynamic, in situ measurement of sea-ice characteristic length

Lifetime estimation for a land-fast ice sheet subjected to ocean swell

Ocean wave speed in the Antarctic marginal ice zone

Platelet ice and the land-fast sea ice of McMurdo Sound, Antarctica

Biomass, production and microhabitat characteristics near the freeboard of ice floes in the Ross Sea, Antarctica, during the austral summer

Biomass, production and microhabitat characteristics near the freeboard of ice floes in the Ross Sea, Antarctica, during the austral summer

Interannual variability of the Storfjorden (Svalbard) ice cover and ice production observed by ERS-2 SAR

Seasonal transformation of water masses, circulation and brine formation observed in Storfjorden, Svalbard

The Ronne polynya of 1997/98: observations of air-ice--ocean interaction

Behaviour of dissolved organic matter and inorganic nutrients during experimental sea-ice formation

Dissolved organic matter in Antarctic sea ice

Biomass, production and microhabitat characteristics near the freeboard of ice floes in the Ross Sea, Antarctica, during the austral summer teleconnections

Brine percolation and the transport properties of sea ice

Decadal variability in high northern latitudes as simulated by an intermediate-complexity climate model

An observational and modelling analysis of Laptev Sea (Arctic Ocean) ice variations during summer

Observations on sea-ice and surface-water geochemistry - implications for importance of sea ice in geochemical cycles in the northern Baltic Sea

Time-series observations of the structure and properties of brackish ice in the Gulf of Finland Satellite observations of upper-ocean currents in Terra Nova Bay, Antarctica

Vertical zonation and community transition of sea-ice diatoms in fast ice and platelet layer, Weddell Sea, Antarctica conditions

Sea-ice kinematics measured with GPS drifters by ERS-2 SAR Storfjorden, Svalbard

Decadal variability in high northern latitudes as simulated by an intermediate-complexity climate model

Behaviour of dissolved organic matter and inorganic nutrients during experimental sea-ice formation

The seasonal cycle of ERS scatterometer signatures over perennial Antarctic sea ice and associated surface ice properties and processes

Response of the Northern Hemisphere sea ice to greenhouse forcing in a global climate model 
HARANGOZO, S

HARMS, S

HASKELL, T G

HASKELL, TG

HASKELL, T G

HASKELL, T G

HASKELL, T G

HAUGAN, P M

HAUGAN, P M

HEIL, P

HELBIG, A

HELLMER, H H

HEYGSTER, G

HIBLER, W D, III

HIGGINS, A K

HILL, B T

HILL, K L

HÖLEMANN, JA

HOLMGREN, J

HOPKINS, M A

HOPKINS, M A

HUNKE, E C

HURST-CUSHING, B

IKEDA, M

ISHIKAWA, N

JEFFERS, S

JEFFRIES, MO

JEFFRIES, MO

JEFFRIES, MO

JEFFRIES, MO

JEZEK, K G

JOHNSON, M

JONES, SJ

JUNGE, K

JUOTTONEN, A
The simulation of Antarctic sea ice in the Hadley Centre Climate Model (HadCM3)

Combined satellite- and ULS-derived sea-ice flux in the Weddell Sea, Antarctica

Dynamic, in situ measurement of sea-ice characteristic length

Ice-floe kinematics in the Ross Sea marginal ice zone using GPS and accelerometers

Lifetime estimation for a land-fast ice sheet subjected to ocean swell

Ocean wave speed in the Antarctic marginal ice zone

Platelet ice and the land-fast sea ice of McMurdo Sound, Antarctica

Interannual variability of the Storfjorden (Svalbard) ice cover and ice production observed by ERS-2 SAR

Seasonal transformation of water masses, circulation and brine formation observed in Storfjorden, Svalbard

A comparison of East Antarctic sea-ice motion derived using drifting buoys and remote sensing

An observational and modelling analysis of Laptev Sea (Arctic Ocean) ice variations during summer

The role of sea ice in the fresh-water budget of the Weddell Sea, Antarctica

Sea-ice concentration retrieval in the Antarctic based on the SSM/I $85.5 \mathrm{GHz}$ polarization

Modeling the formation and evolution of oriented fractures in sea ice

Sea ice and the stability of north and northeast Greenland floating glaciers

Structure of sea ice in McMurdo Sound, Antarctica

Effects of regional fast-ice and iceberg distributions on the behaviour of the Mertz Glacier polynya, East Antarctica

The Laptev Sea flaw polynya, Russian Arctic: effects on the mesoscale hydrography

Spatial variations in the winter heat flux at SHEBA: estimates from snow-ice interface temperatures

A conceptual model for pancake-ice formation in a wave field

Simulation of pancake-ice dynamics in a wave field

425

Time-series observations of the structure and properties of brackish ice in the Gulf of Finland

Investigating the anomalous sea-ice conditions in the Canadian High Arctic (Queen Elizabeth Islands) during summer 1998

Phase and compositional evolution of the flooded layer during snow-ice formation on

Antarctic sea ice

Sea-ice thickness and roughness in the Ross Sea, Antarctica

Seasonal contrasts in snow-cover characteristics on Ross Sea ice floes

61

Snow-ice accretion and snow-cover depletion on Antarctic first-year sea-ice floes

The onset of Arctic sea-ice snowmelt as detected with passive- and active-microwave remote sensing

Modelling the variability of the sea-ice conditions in the Baltic Sea under different climate conditions 
KASSENS, H

KATTNER, G

KATTNER, G

KAWAMURA, T

KENNEDY, H

KENNEDY, H

KERN, S

KEY, J R

KING, DJ

KING, JC

KIRILLOV, S

KOBAYASHI, $\mathrm{T}$

KREMBS, C

KROUSE, H R

LANDMAN, K A

LANGHORNE, PJ

LANGHORNE, PJ

LAUNIAINEN, J

LAUNIAINEN, J

LEPPÄRANTA, M

LEPPÄRANTA, M

LEPPÄRANTA, M

LI, S

LINDFORS, A

LINDSAY, RW

LIU, A K

LIU, X

LONG, D G

LYTLE, V I

LYTLE, V I

LYTLE, V I

LYTLE, V I

MAENO, H

MAKSYM, T

MAKSYM, T
The Laptev Sea flaw polynya, Russian Arctic: effects on the mesoscale hydrography

Behaviour of dissolved organic matter and inorganic nutrients during experimental sea-ice formation

Dissolved organic matter in Antarctic sea ice

297

Time-series observations of the structure and properties of brackish ice in the Gulf of Finland

Behaviour of dissolved organic matter and inorganic nutrients during experimental sea-ice formation

Dissolved organic matter in Antarctic sea ice

297

Sea-ice concentration retrieval in the Antarctic based on the SSM/I $85.5 \mathrm{GHz}$ polarization

Spatial variability of the sea-ice radiation budget and its effect on aggregate-area fluxes

A case-study in tracking 1998 polynya ice dynamics in Smith Sound, North Water polynya region, Canadian Arctic, using RADARSAT-1 data

The Ronne polynya of 1997/98: observations of air-ice-ocean interaction

The Laptev Sea flaw polynya, Russian Arctic: effects on the mesoscale hydrography

GRL/NASDA airborne SAR (Pi-SAR) observations of sea ice in the Sea of Okhotsk

A microscopic approach to investigate bacteria under in situ conditions in sea-ice samples

Snow-ice accretion and snow-cover depletion on Antarctic first-year sea-ice floes

Solar radiative heating in first-year sea ice

Lifetime estimation for a land-fast ice sheet subjected to ocean swell

Platelet ice and the land-fast sea ice of McMurdo Sound, Antarctica

Modelling sea-ice thermodynamics in BALTEX-BASIS

Turbulent surface fluxes and air-ice coupling in Baltic-Air-Sea-Ice Study (BASIS)

Modelling the variability of the sea-ice conditions in the Baltic Sea under different climate conditions

Sea-ice kinematics measured with GPS drifters

555

Time-series observations of the structure and properties of brackish ice in the Gulf of Finland

Measurement of all-wave and spectral albedos of snow-covered summer sea ice in the Ross Sea, Antarctica

Time-series observations of the structure and properties of brackish ice in the Gulf of Finland

Arctic sea-ice albedo derived from RGPS-based ice-thickness estimates

Principal-component analysis of sea-ice motion from satellite data

Combined satellite- and ULS-derived sea-ice flux in the Weddell Sea, Antarctica

The onset of Arctic sea-ice snowmelt as detected with passive- and active-microwave remote sensing

Effects of regional fast-ice and iceberg distributions on the behaviour of the Mertz Glacier polynya, East Antarctica

Ice formation in the Mertz Glacier polynya, East Antarctica, during winter

Sensible- and latent-heat-flux estimates over the Mertz Glacier polynya, East Antarctica, from in-flight measurements

Snow-ice growth: a fresh-water flux inhibiting deep convection in the Weddell Sea, Antarctica

CRL/NASDA airborne SAR (Pi-SAR) observations of sea ice in the Sea of Okhotsk

Phase and compositional evolution of the flooded layer during snow-ice formation on

Antarctic sea ice

Snow-ice accretion and snow-cover depletion on Antarctic first-year sea-ice floes
17 7 7 . . (5)

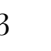

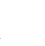

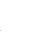


MARBLE, D C

MARNELA, M

MARTINSON, D G

MARTMA, T

MASLANIK, JA

MASLANIK, JA

MASLOWSKI, W

MASSOM, R A

MASSOM, R A

MATSUOKA, T

MATSUOKA, T

McCOURT, S

McGUINNESS, MJ

MEIER, W N

MEIER, W N

MEIER, W N

MICHAEL, KJ

MORRIS, K

MORRIS, K

NADAI, A

NAKAMURA, K

NAKAMURA, K

NAZARENKO, L

NAZARENKO, L

NEENAN, D R

NISHIO, F

NISHIO, F

O'DWYER, J

OPSTEEGH, J D

ØSTERHUS, S

PAGET, M J

PAGET, MJ
On large-scale shifts in the Arctic Ocean and sea-ice conditions during 1979-98

Modelling the variability of the sea-ice conditions in the Baltic Sea under different climate conditions

An efficient adjustable-layering thermodynamic sea-ice model formulation for highfrequency forcing

Time-series observations of the structure and properties of brackish ice in the Gulf of Finland

A comparison of East Antarctic sea-ice motion derived using drifting buoys and remote sensing

Synoptic-scale ice-motion case-studies using assimilated motion fields

On large-scale shifts in the Arctic Ocean and sea-ice conditions during 1979-98

Effects of regional fast-ice and iceberg distributions on the behaviour of the Mertz Glacier polynya, East Antarctica

Ice formation in the Mertz Glacier polynya, East Antarctica, during winter

GRL/NASDA airborne SAR (Pi-SAR) observations of sea ice in the Sea of Okhotsk

Estimation of sea-ice physical parameters using polarimetric SAR: results from Okhotsk and Lake Saroma campaign

Investigating the anomalous sea-ice conditions in the Canadian High Arctic (Queen Elizabeth Islands) during summer 1998

Solar radiative heating in first-year sea ice

Evaluation of operational SSM/I ice-concentration algorithms

Satellite observations of upper-ocean currents in Terra Nova Bay, Antarctica

Synoptic-scale ice-motion case-studies using assimilated motion fields

Determining the floe-size distribution of East Antarctic sea ice from digital aerial photographs

Measurement of all-wave and spectral albedos of snow-covered summer sea ice in the Ross Sea, Antarctica

Seasonal contrasts in snow-cover characteristics on Ross Sea ice floes

GRL/NASDA airborne SAR (Pi-SAR) observations of sea ice in the Sea of Okhotsk

CRL/NASDA airborne SAR (Pi-SAR) observations of sea ice in the Sea of Okhotsk

Estimation of sea-ice physical parameters using polarimetric SAR: results from Okhotsk and Lake Saroma campaign

Modeling of the Beaufort ice--ocean climatology change

Response of the Northern Hemisphere sea ice to greenhouse forcing in a global climate model

Biomass, production and microhabitat characteristics near the freeboard of ice floes in the Ross Sea, Antarctica, during the austral summer

CRL/NASDA airborne SAR (Pi-SAR) observations of sea ice in the Sea of Okhotsk

Estimation of sea-ice physical parameters using polarimetric SAR: results from Okhotsk and Lake Saroma campaign

Seasonal transformation of water masses, circulation and brine formation observed in Storfjorden, Svalbard

Decadal variability in high northern latitudes as simulated by an intermediate-complexity climate model

Seasonal transformation of water masses, circulation and brine formation observed in Storfjorden, Svalbard

Determining the floe-size distribution of East Antarctic sea ice from digital aerial photographs

Effects of regional fast-ice and iceberg distributions on the behaviour of the Mertz Glacier polynya, East Antarctica

Ice formation in the Mertz Glacier polynya, East Antarctica, during winter
368

115

\section{3}

91 
PANTOJA, A E

PAULSON, G A

PEGAU, W S

PEGAU, W S

PELLEGRINI, A

PEROVICH, D K

PEROVICH, D K

PEROVICH, D K

PEROVICH, D K

PEROVICH, D K

PROSHUTINSKY, A

PROSHUTINSKY, T

RASMUS, K

REEH, N

RICHTER-MENGE, JA Seasonal changes in Arctic sea-ice morphology

RICHTER-MENGE, JA Summer ice dynamics during SHEBA and its effect on the ocean heat content

RINKE, A

ROBERTS, A

ROBERTS, A

RUEDY, R

SATAKE, M

SCHAUER, U

SELTEN, F M

SEMTNER, AJ

SEMTNER, AJ

SHEN, H H

SHEN, H H

SHIRASAWA, K

SMITH, IJ

SMITH, R G

SQUIRE, VA

SQUIRE, VA

STAMMERJOHN, S E

STEINER, N

STIERLE, A region
Solar radiative heating in first-year sea ice

The albedo of Arctic leads in summer

The albedo of Arctic leads in summer

Summer ice dynamics during SHEBA and its effect on the ocean heat content

Satellite observations of upper-ocean currents in Terra Nova Bay, Antarctica

Indirect measurements of the mass balance of summer Arctic sea ice with an electromagnetic induction technique

Seasonal changes in Arctic sea-ice morphology

Spatial variations in the winter heat flux at SHEBA: estimates from snow-ice interface temperatures

Summer ice dynamics during SHEBA and its effect on the ocean heat content

Temporal evolution of Arctic sea-ice temperature

Understanding climatic controls on sea-ice transport pathways in the Arctic Ocean

Understanding climatic controls on sea-ice transport pathways in the Arctic Ocean

551

Time-series observations of the structure and properties of brackish ice in the Gulf of Finland summer

Ice formation in the Mertz Glacier polynya, East Antarctica, during winter

Sensible- and latent-heat-flux estimates over the Mertz Glacier polynya, East Antarctica, from in-flight measurements

Response of the Northern Hemisphere sea ice to greenhouse forcing in a global climate model

CRL/NASDA airborne SAR (Pi-SAR) observations of sea ice in the Sea of Okhotsk

Seasonal transformation of water masses, circulation and brine formation observed in Storfjorden, Svalbard

Decadal variability in high northern latitudes as simulated by an intermediate-complexity climate model

The Antarctic Circumpolar Wave in a global, high-resolution, coupled ice--ocean model

On large-scale shifts in the Arctic Ocean and sea-ice conditions during 1979-98

Simulation of pancake-ice dynamics in a wave field

A conceptual model for pancake-ice formation in a wave field

Time-series observations of the structure and properties of brackish ice in the Gulf of Finland

Platelet ice and the land-fast sea ice of McMurdo Sound, Antarctica

Variations of surface air temperature and sea-ice extent in the western Antarctic Peninsula region

How a region of cracked sea ice affects ice-coupled wave propagation

Lifetime estimation for a land-fast ice sheet subjected to ocean swell

Introduction of variable drag coefficients into sea-ice models

A microscopic approach to investigate bacteria under in situ conditions in sea-ice samples 
STIPA, T

STURM, M

TATEYAMA, K

TAUSNEV, N

TAUSNEV, $\mathrm{N}$

THOMAS, D N

THOMAS, D N

THOMSEN, H H

TIMMERMANN, R

TIN, T

TISON, J-L

TOUDAL, L

TOYOTA, T

TRODAHL, H J

TRODAHL, H J

TUCKER, W B, III

TUCKER, W B, III

TUOMENVIRTA, H

TURNER, J

TYSHKO, K

TZIPERMAN, E

UKITA, J

UMEHARA, T

UOTILA, J

UOTILA, J

URATSUKA, S

VAIKMÄE, R

VAN WOERT, M L

VAN WOERT, M L

VENNELL, M R

VERBEKE, V

VIHMA, T

VIHMA, T

VIRKANEN, J
Sea-ice kinematics measured with GPS drifters

Spatial variations in the winter heat flux at SHEBA: estimates from snow-ice interface temperatures

Observation of sea-ice thickness fluctuation in the seasonal ice-covered area during 1992-99 winters

449

Modeling of the Beaufort ice--ocean climatology change

Response of the Northern Hemisphere sea ice to greenhouse forcing in a global climate model

Behaviour of dissolved organic matter and inorganic nutrients during experimental sea-ice formation

Dissolved organic matter in Antarctic sea ice

Sea ice and the stability of north and northeast Greenland floating glaciers

The role of sea ice in the fresh-water budget of the Weddell Sea, Antarctica

Sea-ice thickness and roughness in the Ross Sea, Antarctica

187

Chlorinity/salinity distribution patterns in experimental granular sea ice

Interannual variability of the sea-ice-induced salt flux in the Greenland Sea

Characteristics of the surface heat budget during the ice-growth season in the southern Sea of Okhotsk

Platelet ice and the land-fast sea ice of McMurdo Sound, Antarctica

Solar radiative heating in first-year sea ice

Indirect measurements of the mass balance of summer Arctic sea ice with an electromagnetic induction technique

Seasonal changes in Arctic sea-ice morphology

Modelling the variability of the sea-ice conditions in the Baltic Sea under different climate conditions

The simulation of Antarctic sea ice in the Hadley Centre Climate Model (HadCM3)

The Laptev Sea flaw polynya, Russian Arctic: effects on the mesoscale hydrography

Sea ice, as the glacial cycles' climate switch, and interhemispheric thermohaline teleconnections

An efficient adjustable-layering thermodynamic sea-ice model formulation for highfrequency forcing

CRL/NASDA airborne SAR (Pi-SAR) observations of sea ice in the Sea of Okhotsk

Modelling sea-ice thermodynamics in BALTEX-BASIS

Turbulent surface fluxes and air-ice coupling in Baltic-Air-Sea-Ice Study (BASIS)

CRL/NASDA airborne SAR (Pi-SAR) observations of sea ice in the Sea of Okhotsk

Time-series observations of the structure and properties of brackish ice in the Gulf of Finland

Evaluation of operational SSM/I ice-concentration algorithms

Satellite observations of upper-ocean currents in Terra Nova Bay, Antarctica

Platelet ice and the land-fast sea ice of McMurdo Sound, Antarctica

Chlorinity/salinity distribution patterns in experimental granular sea ice

Modelling sea-ice thermodynamics in BALTEX-BASIS

Turbulent surface fluxes and air-ice coupling in Baltic-Air-Sea-Ice Study (BASIS)

Observations on sea-ice and surface-water geochemistry - implications for importance of sea ice in geochemical cycles in the northern Baltic Sea 
WAKABAYASHI, $\mathrm{H}$

WAKABAYASHI, $\mathrm{H}$

WAKATSUCHI, M

WALCZOWSKI, W

WALSH, JE

WANG, J

WANG, X

WEATHERLY, J W

WEIDICK, A

WENDLER, G

WILLIAMS, GD

WILSON, KJ

WORBY, A P

WORBY, A P

WORBY, A P

WORBY, A P

WORBY, A P

WORBY, A P

WU, X

WU, X

ZHANG, Y

ZHANG, Z

ZHAO, Y

ZHOU, X

ZOU, C-Z
CRL/NASDA airborne SAR (Pi-SAR) observations of sea ice in the Sea of Okhotsk

Estimation of sea-ice physical parameters using polarimetric SAR: results from Okhotsk and Lake Saroma campaign

Characteristics of the surface heat budget during the ice-growth season in the southern Sea of Okhotsk

On large-scale shifts in the Arctic Ocean and sea-ice conditions during 1979-98

444

20th-century sea-ice variations from observational data

481

Arctic sea-ice oscillation: regional and seasonal perspectives

Sea ice and climate in 20th- and 21st-century simulations with a global atmosphere-oceanice model

Sea ice and the stability of north and northeast Greenland floating glaciers

474

The surface energy budget in the Antarctic summer sea-ice pack

Sea-ice growth and water-mass modification in the Mertz Glacier polynya, East Antarctica, during winter

A case-study in tracking 1998 polynya ice dynamics in Smith Sound, North Water polynya region, Canadian Arctic, using RADARSAT-1 data

Determining the floe-size distribution of East Antarctic sea ice from digital aerial photographs

Effects of regional fast-ice and iceberg distributions on the behaviour of the Mertz Glacier polynya, East Antarctica

Ice formation in the Mertz Glacier polynya, East Antarctica, during winter

Seasonal development of sea-ice thickness distribution in East Antarctica: measurements from upward-looking sonar data

Sensitivity of the Antarctic sea-ice distribution to oceanic heat flux in a coupled atmospheresea-ice model

The surface energy budget in the Antarctic summer sea-ice pack

Ice formation in the Mertz Glacier polynya, East Antarctica, during winter

Sensitivity of the Antarctic sea-ice distribution to oceanic heat flux in a coupled atmospheresea-ice model

The Antarctic Circumpolar Wave in a global, high-resolution, coupled ice- ${ }^{-}$ocean model

Sea-ice kinematics measured with GPS drifters

Principal-component analysis of sea-ice motion from satellite data

Measurement of all-wave and spectral albedos of snow-covered summer sea ice in the Ross Sea, Antarctica

Satellite observations of upper-ocean currents in Terra Nova Bay, Antarctica 